\title{
Publisher Correction to: Goodness-of-fit test for $\alpha$ - stable distribution based on the quantile conditional variance statistics
}

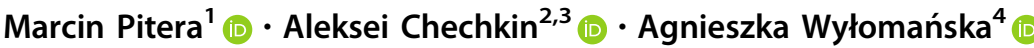

Accepted: 7 July 2021 / Published online: 21 July 2021

(C) The Author(s) 2021

\section{Publisher Correction to: Statistical Methods \& Applications https:// doi.org/10.1007/s10260-021-00571-9}

Due to a technical processing error several formulas have been incorrectly represented in the original PDF of this article. The original article PDF has been corrected. The HTML version was unaffected.

Open Access This article is licensed under a Creative Commons Attribution 4.0 International License, which permits use, sharing, adaptation, distribution and reproduction in any medium or format, as long as you give appropriate credit to the original author(s) and the source, provide a link to the Creative Commons licence, and indicate if changes were made. The images or other third party material in this article are included in the article's Creative Commons licence, unless indicated otherwise in a credit line to the material. If material is not included in the article's Creative Commons licence and your intended use is not permitted by statutory regulation or exceeds the permitted use, you will need to obtain permission directly from the copyright holder. To view a copy of this licence, visit http:// creativecommons.org/licenses/by/4.0/.

Publisher's Note Springer Nature remains neutral with regard to jurisdictional claims in published maps and institutional affiliations.

The original article can be found online at https://doi.org/10.1007/s10260-021-00571-9.

Marcin Pitera

marcin.pitera@uj.edu.pl

1 Institute of Mathematics, Jagiellonian University, S. Łojasiewicza 6, 30-348 Kraków, Poland

2 Institute of Physics \& Astronomy, University of Potsdam, Potsdam-Golm, Germany

3 Akhiezer Institute for Theoretical Physics NSC "Kharkov Institute of Physics and Technology", Kharkov, Ukraine

4 Faculty of Pure and Applied Mathematics, Hugo Steinhaus Center, Wrocław University of Science and Technology, Wyspiańskiego 27, 50-370 Wrocław, Poland 